\title{
Social Service (PKM) of Application of Population Data Collection in RT. 004, Kalisuren
}

\section{PKM Penerapan Aplikasi Pendataan Penduduk di RT. 004 Kalisuren}

\author{
Ulfa Pauziah, Dewi Mustari*, \& Triyani Akhirina
}

Informatika, Universitas Indraprasta PGRI, Indonesia

\begin{abstract}
The development of technology in modern times today encourages every aspect of work to be done through the computerization, with the aim to facilitate the processing of data. In addition, by the application of technology, the time and place for data storage will be more efficient, resulting in accurate and accurate residents' data, and can be conveyed properly to those in need. Manual data processing is considered less effective in processing and calculating the large data, and this can result in the data loss. These undesirable mistakes will be very detrimental to the development of residents' data contained in RT 04, Kalisuren. By the presence of the data collection application for the residents in RT 04, Kalisuren, the data collection process for both births and deaths that occurred in RT 04 Kalisuren can be carried out properly.
\end{abstract}

\begin{abstract}
Abstrak
Teknologi yang semakin berkembang mendorong setiap aspek untuk merubah pekerjaan yang tadinya dikerjakan secara manual menjadi komputerisasi. Dengan tujuan mepermudah dalam proses pengelohan data. Selain itu dengan adanya aplikasi dapat mengefisienkan waktu dan tempat penyimpanan data. Oleh karena itu untuk menghasilkan data warga yang tepat dan akurat, agar dapat disampaikan dengan baik kepada yang membutuhkan. Pengolahan data secara manual bukanlah suatu hal yang salah, namun cara tersebut kurang efektif untuk melakukan pengolahan dan perhitungan data yang besar, dan hal ini dapat mengakibatkan terjadinya kehilangan data. Kesalahan-kesalahan yang tidak diinginkan itu akan sangat merugikan untuk perkembangan pedataan warga yang terdapat pada RT 04 Kalisuren. Dengan adanya aplikasi pendataan warga RT 04 kalisuren dapat membantu RT dalam proses pendataan baik kelahiran ataupun kematian yng terjadi di RT 04 kalisuren.
\end{abstract}

(C) 2020 Author(s).

Keywords: Applications, Technology, Data.

\section{Pendahuluan}

Penduduk dunia saat ini telah mencapai lebih dari 6 miliar, dimana diantara jumlah tersebut $80 \%$ dari jumlah tersebut tinggal dinegara-negara berkembang (Jogiyanto, 1999). Sementara itu United Nation (2001) memproyeksikan bahwa penduduk perkotaan dinegara-negara berkembang terus meningkat dengan rata-rata 2,4\% per tahun. Angka ini merupakan dua kali lipat angka pertumbuhan penduduk total negara-negara berkembang pada umumnya, yakni

\footnotetext{
* Corresponding author:

E-mail address: mustaridewi@yahoo.com (Dewi Mustari)
} 
sekitar $1,2 \%$. Meski penduduk perkotaan dinegara-negara maju juga meningkat dengan angka pertumbuhan yang lebih besar daripada angka pertumbuhan penduduk totalny (Pusat Data dan Informasi Pendidikan Depdiknas, 2003).

Maksud dan tujuan dari pendataan warga pada RT 04 Kalisuren adalah untuk menghasilkan data warga yang tepat dan akurat, agar dapat disampaikan dengan baik kepada yang membutuhkan. Sistem pendataan warga pada RT 04 Kalisuren masih dilakukan secara manual seperti pembuatan laporan dan pencatatan. Pengolahan data secara manual bukanlah suatu hal yang salah, namun cara tersebut kurang efektif untuk melakukan pengolahan dan perhitungan data yang besar, dan hal ini dapat mengakibatkan terjadinya kehilangan data. Kesalahan-kesalahan yang tidak diinginkan itu akan sangat merugikan untuk perkembangan pedataan warga yang terdapat pada RT 04 Kalisuren.

Dari analisa yang telah dilakukan permasalahan yang kerap berlangsug pada saat pendataan warga RT 04 Kalisuren yaitu bertumpuknya data warga yang telah didata, karena pendataan warga dilakukan secara manual atau konvensional sehingga menyulitkan pada saat akan mencari data warga. Pendataan warga sangatlah penting untuk pengolahan data sehingga dapat menghasilkan data warga yang tepat dan akurat, agar dapat disampaikan dengan baik kepada yang membutuhkan khususnya RT 04 Kalisuren.

Cara pendataan warga masih dilakukan secara manual dalam pembuatan laporan dan pencatatannya, maka peneliti berusaha merancang sistem tersebut guna membantu dalam penyampaian informasi pendataan warga dan membantu menyelesaikan masalah yang jadi kendala dalam pendataan warga RT 04 Kalisuren.

Berdasarkan permasalahan yang telah diuraikan, maka tujuan dari kegiatan ini adalah:

1. Mengimplementasikan aplikasi pendataan warga khususnya pendataan warga RT 04 kalisuren,

2. Memberikan pelatihan bagaimana cara menggunakan aplikasi pendataan warga RT 04 kalisuren dalam mengolah data warga nya.

3. Mengevaluasi apakah aplikasi pendataan warga RT 04 kalisuren bisa berjalan dengan baik dan membantu user (pak RT) dalam mengelola data warga RT 04 Kalisuren.

Setelah menganalisis dan memahami permasalahan yang ada, maka kami menawarkan solusi yang dapat memacahkan permasalahan tersebut. Solusi yang ditawarkan yaitu

1. Dengan membuat aplikasi pendataan warga yang diharapkan dapat membantu pa RT 04 kalisuren dalam mengelola data warganya.

2. Memberikan pengetahuan betapa pentingnya pengetahuan mengenai teknologi dan dapat mempermudah dalam pekerjaan sehingga dapat mengefisienkan waktu yang dibutuhkan.

3. Membatu dalam pengelolaan data kelahiran dan kematian warga yang berda di RT 04 kalisuren.

4. Memberikan pelatihan kepada pa RT yang mengelola mengenai data warga 04 Kalisuren.

Luaran yang ditargetkan dari kegiatan Iptek Kepada Masyarakat $\left(\mathrm{I}_{\mathrm{b}} \mathrm{M}\right)$ adalah

1. Mengubah sistem pendataan warga RT 04 Kalisuren yang tadinya dilakukan dengan cara manual atau konvensional dengan sistem informasi pendataan warga berbasis aplikasi (Terkomputerisasi).

2. Membatu pekerjaan pa RT pendataan warga RT 04 Kalisuren agar lebih efisien dan efektif dalam pengolahan data warga.

\section{Pelaksanaan dan Metode}

Berdasarkan masalah yang dihadapi, maka langkah-langkah yang dilkakukan untuk mencapai tujuan dan sasaran bagi kegiatan ini maka diadakan pendekatan kepada instansi terkait yaitu RT 04 Kalisuren. melalui pelatihan berupa 
penjelasan atau uraian mengenai penggunaan teknologi aplikasi pendataan warga sebagai alat untuk membantu pekerjaan dalam pendataan warga. Kegiatan tersebut bertujuan memberikan pengarahan dan cara penggunaan aplikasi pendataan warga. Pelatihan ini akan di bimbing oleh tim pelaksana staf pengajar dari Jurusan Teknik Informatika Universitas Indraprasta PGRI.

Pelaksanaan kegiatan ini dilakukan dalam tiga tahap, yakni tahap persiapan, pelaksanaan dan evaluasi.

1. Tahap Persiapan. Pada tahap ini tim melakukan survei pendahuluan untuk mengetahui kondisi target kegiatan dengan menganalisis kondisi tempat yang akan digunakan, kondisi peserta yang akan diberikan perlakuan dan menyusun rancangan kegiatan yang akan dilakukan. Tahap persiapan selanjutnya tim menyiapkan bahan-bahan yang akan dijadikan materi persentasi.

2. Tahap Pelaksanaan yaitu, tim pelaksana melakukan. Pelatihan kepada RT 04 Kalisuren dengan menyampaikan materi mengenai bagaimana penggunaan teknologi aplikasi pendataan warga untuk keperluan keperluan pengolahan data kelahiran, kematian dan lain-lain. Sehingga dapat membantu pekerjaan yang berhubungan dengan pendataan warga RT 04 kalisuren.

3. Evaluasi dilakukan untuk mengukur tingkat keberhasilan suatu kegiatan implementasi aplikasi pendataan warga RT.04 kalisuren. Evaluasi dilakukan berupa wawancara langsung dengan pa RT sebagai user dari aplikasi pendataan warga.

\section{Hasil dan Pembahasan}

Perkembangan teknologi informasi semakin hari semakin pesat. Bukan hanya digunakan diperusahaan-perusahan besar saa, tapi saat ini sudah menyentuh ke perusahaan-perusahaan kecil dan juga kantor-kantor negeri seperti desa bahkan di Rukun warga dan RT sudah menggunakan aplikasi untuk mendata warga nya. Diperkuat dengan pendapat (Awaludin, dkk, 2019: 68) menyatakan bahwa Perkembangan teknologi dan komunikasi saat ini turut memberikan dampak positif juga dalam bidang kependidikan dan lingkungan, dan Melalui media tersebut memungkinkan akses informasi untuk promosi serta pemasaran yang dapat dilakukan seluas-luasnya tanpa terbatas ruang dan waktu (Diana,dkk, 2017). Mau tidak mau pengurus ditingkat RT harus mau belajar bagaimana menggunakan aplikasi untuk mendata warga nya agar semua data warga khususnya RT 04 kalisuren dapat disimpan dan diakses dengan mudah.

Pemanfaatan teknologi ini khususnya aplikasi pendataan warga RT 04 kalisuren sebagai implementasi dari aplikasi pendataan warga yang kami buat untuk mempermudah pendataan warga RT 04 kalisuren yang saat ini masih penggunakan cara konvensional atau manual (Irnawan., 2006). Yang terkadang pa rt harus mencari di dalam berkas saat warga nya membutuhkan pembuatan surat-surat, yang terkadang data nya keselip bahkan hilang. Oleh sebab itu, kami membuat aplikasi pendataan warga ini untuk memprmudah dalam mengelola data warga di RT 04 kalisuren.

Sebelum menggunakan aplikasi pendataan penduduk untuk warga RT 04 Kalisuren, tentunya kami tim pengabdian masyarakat dari Universitas Indraprasta PGRI harus memberikan pelatihan. Pelatihan yang kami berikan adalah bagaimana cara menggunakan aplikasi pendataan penduduk untuk RT 04 kalisuren dalam mengelola data warganya. Tentunya kami juga memberikan buku panduan pemakaian aplikasi untuk mempermudah pa rt dalam menggunakan aplikasi tersebut.

Setelah apalikasi pendataan penduduk untuk warga RT 04 Kalisuren di terapkan tentunya kami harus mengevaluasi apakah aplikasi pendataan warga RT 04 kali suren berhasil. Artinya bisa membantu serta meringankan pekerjaan pa rt dalam mengelola data warganya. Selain itu untuk menilai apakah aplikasi pendataan tersebut masih ada kekurangan atau error. Sehingga kami bisa memberikan yang pelayanan yang baik untuk masyarat. Dengan memberikan yang dibutuhkan, tentunya sesuai dengan bidang kami yaitu sebagai peracang dan pembuat aplikasi.

Dengan di laksanakannya kegiatan pengabdian kepada masyarakat yaitu pelatihan pengunaan aplikasi pendataan warga di RT 04 kalisuren. Memiliki tujuan atau hasil yang di dapat dari pelatihan tersebut yaitu

1. Ketua RT 04 kalisuren dapat menggunakan aplikasi pendataan penduduk untuk warganya yang dapat membantu dalam pengelolaan data warga. 
2. Dengan dilaksanakannya pengabdian masyarakat mengenai pengimplementasian aplikasi pendataan warga, diharapkan dapat meringankan pekerjaan Ketua RT 04 kalisuren dalam mendata warga nya.

\section{Kesimpulan dan Saran}

\subsection{Kesimpulan}

Dari kegitan pengabdian masyarakat yang telah dilakukan oleh tim dapat ditarik kesimpulan sebagai berikut:

a. Dengan adanya pengabdian masyarakat ini, diharapkan aplikasi yang kami buat dapat bermanfaat bagi masyarakat khususnya RT 04 kalisuren.

b. Dengan adanya pengabdian masyarakat ini, tentunya kami berharap masyarakat bisa memanfaatkan teknologi untuk kepentingan pekerjaan yang tentunya dapat meringankan dan membantu dalam menyesaikan tugas sebagai RT 04 kalisuren.

c. Dengan mengimplentasikan program pendataan penduduk untuk warga RT 04 Kalisuren, dapat membantu mengevaluasi kekurang dari aplikasi tersebut.

\subsection{Saran}

Pengabdian masyarakat yang dilakukan saat ini agar dapat di pantau hasil nya, pengurus yang menjadi objek pencapaian setelah tim melaksanakan pengabdian masyarakat. Tidak hanya itu pengurus bisa menanyakan hal-hal yang tidak di ketahuinya kepada tim yang sesuai dengan kompetensi tim pengabdian masyarakat.

\section{References}

Awaludin, AAR., Hartuti, PM., Rahadiyan, A. (2019). Aplikasi Cabri 3D Berbantu Camtasia Studio untuk Pembelajaran Matematika di SMP. E-DIMAS: Jurnal Pengabdian kepada Masyarakat, 10(1), 68-75.

Diana, L.F., Any, P.U., Fajar, N. (2017). Pemanfaatan E-Commerce Populer untuk optimalisasi pemasaran produk pada Kub Bordir Kurnia Kudus. Jurnal SIMETRIS Vol.8 No.2.

Jogiyanto. H.M. (1999). Analisa dan Design Sistem Informasi. Andi Offset: Yogyakarta.

Pusat Data dan Informasi Pendidikan Depdiknas. (2003). Pedoman Pendataan Pendidikan. Jakarta.

Irnawan. (2006). Memahami Pemrograman Delphi 7. BSI PRESS: Jakarta. 